\title{
Evaluation of Financial Performance of Commercial Bank of Ethiopia
}

\author{
Yichilal Simegn Filatie \\ Lecturer, Department Of Accounting and Finance \\ College Of Business and Economics, Debre Markos University, Debre Markos, Ethiopia
}

\begin{abstract}
This study was conducted to evaluate the financial performance of commercial bank of Ethiopia, in terms of Capital adequacy, assets quality, management capability, earnings, liquidity and sensitivity to market risk. In this study the data were collected from secondary data sources. The secondary data which covers most of the source are taken from the audited financial statement of commercial bank of Ethiopia. The collected data have been analyzed and presented by using different ratios. The findings of the study revealed that the financial performance of the bank for the period under the study was reasonably good when it is evaluated using audited financial statements. Since debt is known as a cheapest source of fund for business entities than other sources, the bank shall try to increase debt ratio to a reasonable extent and raise additional finance to expand the business as well as increase profitability.
\end{abstract}

Keywords: Commercial Bank of Ethiopia, Financial Performance, Financial analysis

DOI: $10.7176 /$ RJFA/10-23-01

Publication date: December $31^{\text {st }} 2019$

\subsection{Introduction}

The evaluation of financial performance was the subject of how wills a firm can use asset from its primary mode of business and generate revenue. If proper analyzed and interpreted financial statements could provide valuable insight into the firm's performance. Analysis of financial statement is interest to lenders (short term as well as long term), investors, security analysis, managers and others (Chandra, 2001). The study emphasis on different aspect that would be considered as key factors for evaluating the financial condition and performance of most business organization, some of these factors are site and ranking a growth records, financial performance, and quality of management, location, labor management relations, liquidity, leverage, profitability and pattern of exiting stock holding. Each of those factors has their own contribution on general growth of company, therefore to check overall growth of the company consistent evaluation of each factor need to be vital (Sinha, 2010).

Financial analysis involves methods of reclassifying and interpreting financial data contained in financial statement using the help of different tools of analysis. By using the financial performance more important as starting point for planning actions that affects future event information contained in the financial statement of a firm used by management creditor, investors and others to make judgment about the operating performance of the firm(Foster G,1978). So, this study focuses on the evaluation of financial performance of Commercial bank of Ethiopia to measure its profitability and other related risks and also it shows banks strength and weakness. Generally, the main purpose of this study is to measure profitability, liquidity and credit management of commercial bank of Ethiopia, to discussed the financial ratio measurement and analysis, and also to assess the overall financial performance and condition of the bank.

\subsection{Statement of the Problem}

If management helps to maximize bank performance it takes advantage of the banks strength and simultaneously, correct its weaknesses. In this regard the management body of the bank highly on through figures of financial statement. However the absolute amount of priority or asset and liabilities shown in accounts are not usually a particular meaning full criterion on for evaluating financial performance. Appropriate techniques of financial performance evaluations are rare to see in the bank. Therefore information required for management, like if the bank profitable, whether the bank employs effectively its resource and if the bank borrows beyond its capacity or limit (Hempl, G, 1999). At large the accounting profession focuses on how financial statement can be used for financial performance evaluation. Therefore the analyzed financial statement helps the manager to assess the current, past as well as the future financial strength and weakness of firm and makes appropriate decision (Gitman, L. G 2004).

Accordingly, the study focuses on how they are used by management to improve firm's performance and financial position both in firm's position in time and on its operation over in past period. Furthermore, to the best of the researcher's knowledge, only few studies have been conducted on evaluation of financial performance of financial institution in Ethiopia in general and commercial bank of Ethiopia in particular in the Pre and post financial liberalization by using the annual report of the bank. Thus, this study attempted to fill this gap by evaluating the financial performance of the commercial bank of Ethiopia. 


\subsection{Objectives of the study}

1.3.1 General objective

The main objective of this study was to assess the financial performance of Commercial bank of Ethiopia.

\subsubsection{Specific objectives}

To achieve the general objective the following specific objectives were addressed.

$>$ To evaluate the financial performance of commercial bank of Ethiopia.

$>$ To examine how Commercial bank of Ethiopia manage and utilize its total asset to generate revenue.

$>$ To evaluate the financial position of the commercial bank of Ethiopia.

\subsection{Scope of the study}

This study was conducted on evaluation of financial performance of the Commercial bank of Ethiopia. The study was restricted to analyze financial performance of bank by analyzing the four year (2015-2018) financial statement of the bank.

\section{Literature Review}

\subsection{Overview of the financial statement}

The economic event and activities that affect the company and that can be translated in the accounting numbers are reflected in the company's financial statements. Some financial statement provides a picture of the company at a moment in time. Other describe that took place over time. Both provide a basis for evaluating what happened. For example, what rate of growth can be expected next year? These trends provide insight into a market acceptance, profit and liquidity. Consequently a company's financial statement can be used for various purposes: as analytical tool, as a basis for prediction and as a measure of accountability.

\subsection{Types of financial statements}

1) Balance sheet: it is a statement of financial possession, presents the financial possession of a business enterprise on a specific date. It also describe as a photograph of a business at a moment in time

2) Income statement: income statement measures the performance over some period of time, usually quarter or year.

3) Statement of cash flow: statement of cash flow shows the users why firm's investment financial structures have changed between balance sheet data. Simultaneously explain the changes that have been taken place in the firms non-cash asset, liability and stock holder equity account over the same time period. The cash flow statement summarizes cash inflow and outflow of a company broken down in to three principal activities (Horngren S.E, 2001):

\subsection{Overview of financial analysis \\ 2.3.1. Purpose of financial statement analysis}

Financial statement analysis is information processing system designed to provide data for decision making. The information is basically derived from published financial statement but in the process of analysis use is also made of non accounting data such as stock price and aggregate economic indicator. Users of financial statement information system are decision maker concerned with evaluating the economic situation of a firm and predicting its future course. Given the various use and motives it is obvious that no single information will satisfy the entire requirement (Abdu's Sam ad, 2004).

\subsubsection{Users of financial analysis}

Financial analysis can be undertaken by management of the firm, or parties outside the firms: owners, creditors, investors and other. The nature of the analysis will differ depend on the purpose of analyst. Creditors: are interested in the firm's ability to meet their claim over a short period of time. Their analysis will, therefore, confine with the evaluation of the firms liquidity position. Suppliers of long-term debt: are concerned with the firm's long term solvency and survival. They analyzed the firm's profitability over time, its ability to generate cash to be able to pay interest and repay principal the relationship between various sources of funds. Investors: investors who are invested their funds in firms share are most concerned about firms earning. Management: management of the firm would be interested in every aspects of the financial analysis. It is their overall responsibility to see that the resources of firm are used most effectively and efficiently, and that the firm's financial condition is sound (Brigham-2004).

\subsection{Ratio analysis}

Ratio analysis has been the major tool used in the interpretation and evaluation of financial statement for investment decision making. Generally such analysis involves the breaker down of examined financial report into a component part (e.g. fixed and current asset) which are then evaluated in relation to other and exogenous standards. Ratio is indicator of firm's deficiencies such as poor liquidity or low profitability. Thus the negative 
function of ratio is emphasized and favorable ratio may mean nothing unfavorable ratio is significant (Ahmad and Hassan, 2007).

\subsubsection{Objective of ratio analysis}

The major objective of ratio analysis is considered to be facilitation of statement interpretation, this is basically achieved by reducing the large number of financial statement items to relatively small set of ratio such as ratio relate the absolute value financial items to common basis(total asset) allowing a meaningful comparison of financial data both over time and across firms for a given time period, however financial ratio are not intended to provide definite answer their real value is derived from the question they provokes. Ratios are therefore symptom of firms economic condition intended to guide the analysis in the financial investigation (Samad and Hassan, 2000).

\section{Liquidity ratio}

Liquidity refers to the ability of the firm to meet its obligation in the short run, usually one year. Liquidity ratios are generally based on the relationship between current asset the source for meeting short term obligation) and current liability. From the important liquidity ratios are:

Current ratio: it measures the ability of the firm to meet its current liability, current asset converted into cash in the operating cycle of the firm and provide the fund needed to pay current liabilities, the higher current ratio, the greater short term solvency. However, in interpreting current ratio the composition of asset must not be over looked. A firm with a high proportion of current asset in the form of cash and account receivable is more liquid than one with high proportion of current asset in the form of inventories even though both firms have the same current ratio (Brigham, 2004).

\section{Efficiency or Asset Management Ratio}

The objective of this ratio is to indicate various aspects of operational efficiency, attention is focused here. The efficiency of asset utilization is measured by the profitability ratio. There are some ratios here. Fixed asset turnover ratio: it indicate the extent to which firm is using existing property, plant asset and equipment to generate revenue. Higher rate of this ratio are supposed to effect better than average fixed asset management and lower ratio represent poor management.

Total asset turnover ratio: it measures the turnover of all the firms asset it indicate how effectively firm use its total resource to generate sale and is a summery measure influenced by each of the asset management ratio. High rate of this ratio indicate a successful asset management, and low ratio to indicate unsuccessful asset management (Gokulsinha, 2010).

\section{Leverage or Debt Management Ratio}

The purpose of this ratio is to indicate the firm's ability to meet both principal and interest payment on the long term obligation as opposed to short term liquidity ratio; these measures stress the long term financial and operating structure of the firm. The numerator of this ratio consist all liability; short term as well as long term and denominator consist of net worth plus preference capital. In general the lower debt equity ratio is needed mean that the higher the degree of protection enjoyed by creditors. Debt ratio: it measures the extent to which borrowed fund support the firm's asset. Time interest earned ratio: it is supposed to measure how easily the firm can meet its interest obligation. Many times the interest payment is covered by funds that are normally available to pay interest expenses. The lower ratios of time interest indicate the more a firm uses debt than its typical competitors (Hempel, G., \& Simonson, 1999).

\section{Profitability Ratio}

A company should earn profit to survive and grow over a long period of time. Profit are essential, but it would be wrong to assume that every action initiated by a management of the company should be arrived at a maximizing a profit is looked up on a term of a base since some firms always want to maximize profit at a cost of employees, customer and society. Except for such frequent cases, it is fact that sufficient profit must be earned to sustain the operation of the business to be able to obtain funds from investors for expansion and growth and to contribute towards the social over head for the welfare of the society. It will have no future if it fails to make sufficient profit. A manager should continuously evaluate the efficiency of its company in terms of profit. Profitability ratios are calculated to measures the operating efficiency of the firm (Selah and Ramie, 2006).

\subsection{Empirical Evidences}

Abdu's Sam ad (2004) in this paper examines the comparative performance of Bahrain's interest-free Islamic banks and the interest based conventional commercial banks during the post Gulf War period 1991-2001.Using nine financial ratios in measuring the performance with respect to (a)profitability,(b)liquidity risk ,and (c)credit risk, and applying student's t-test to these financial ratios, the paper concludes that there exists a significance difference in profitability and liquidity performance between Islamic banks and conventional banks.

Ahmad and Hassan (2007) analyzed the asset quality, capital ratios, operational ratios such as net profit margin, net interest income, income to asset ratio, non interest income to asset ratio and liquidity ratios for seven years From 1994-2001. Islam banks on an average were the preeminent performer in terms of lowest non- 
performing to gross loan ratio, capital funds to total asset ratio, capital funds to ne t loans, capital funds to short term loan ratio, capital funds to liability ratios, non-interest expense to average asset ratio and most of the liquidity ratios.

Selah and Ramie (2006) In order to evaluate the Islamic banks' performance in Jordon examine and analyze the experience with Islamic banking for the first and second Islamic bank, Jordan Islamic bank for France and investment (JIBFI), and Islamic international Arab Bank (IIAB) in Jordon. The study also highlights the domestic as well as global challenges being faced by this sector. Conducting profit maximization, capital structure, and liquidity tests as performance evaluation methodology, the paper finds the efficiency and ability of both banks have increased and both banks have expanded their investment and activities. Finally, the study concludes that Islamic banks have high growth in the credit facilities and in profitability.

\section{Research Methodology}

3.1. Research Design

The research design employed in this study was descriptive and mixed research approach i.e. both qualitative and descriptive research approaches were used.

\subsection{Type and Source of Data}

The data that would be required to achieve the objective of the study was secondary data. The Secondary data were obtained from annual reports of Commercial bank of Ethiopia.

\subsection{Method of Data Collection}

The type of data to achieve the objective of the study was secondary data. The data were collected from Secondary source from the annual financial statement of Commercial bank of Ethiopia. Basically the reality and validity of good research based on quality data that would be collected. Therefore to get relevant data or information verified financial statement can be used and all necessary precaution was taken, so as to ensure genuine (true) information is obtained.

\subsection{Method of Data Analysis and Presentation}

After the secondary data were collected and analyzed, the data were presented using different tables, diagrams and percentages which used to compare the trends in different years. The bank's financial performance was evaluated using ratio analysis method through graphical and tabular data analysis technique.

\section{Results and Discussion}

\subsection{Introduction}

As explained in chapter one the general objective of this paper was to assess the financial performance of Commercial bank of Ethiopia. The audited financial statement of commercial bank of Ethiopia was analyzed for the past four consecutive years to evaluate the performance of the bank.

\subsection{Ratio Analysis}

Ratio analysis is one of the major tools used in interpretation, analysis and evaluation of financial statement data. In this section the various type of value ratio analysis is used to interpret and evaluates the financial performance in the last four years.

\section{Liquidity Ratio}

It measures the ability of the firm to meet its current obligation. The important liquidity ratio is current and quick ratio. Since the bank is no inventory in the financial statement the researchers use ratio to evaluate the performance of the bank. In the past four years the bank current ratio was fluctuated. As a result the bank has the ability to cover the claim of short term creditors. Graphically it can be shown: 
Fig 4.1 Liquidity Ratio

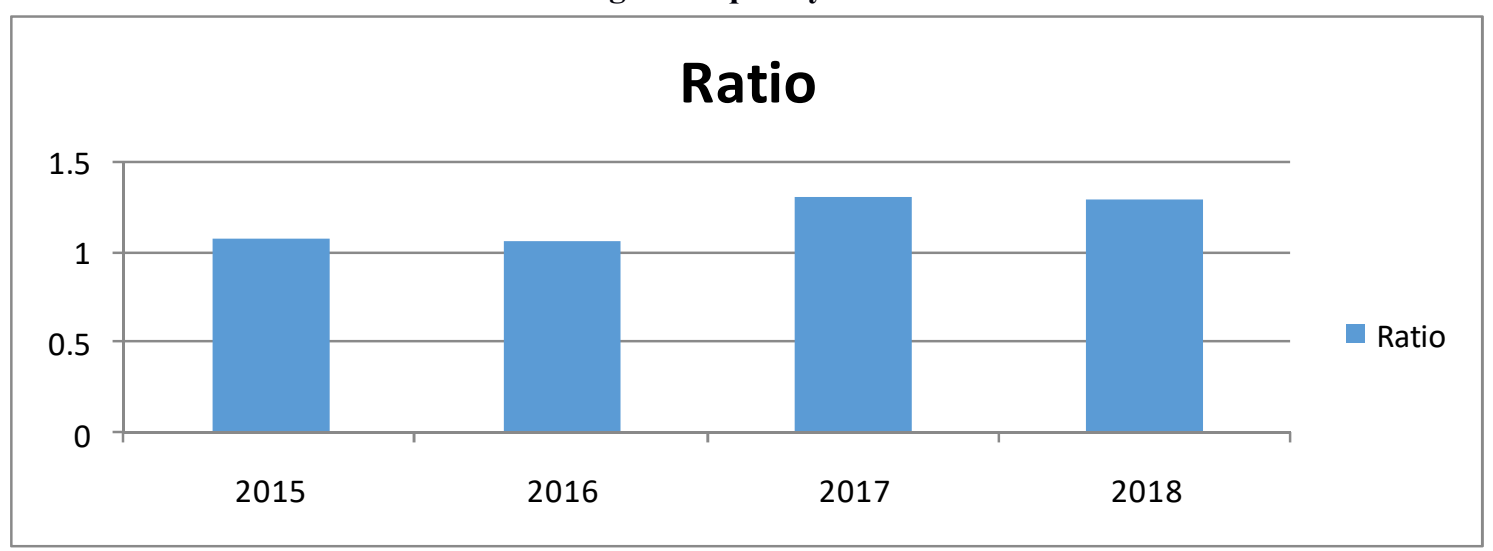

As shown in the above graph in 2015, 2016, 2017 and 2018 the bank has birr 1.07, 1.06, 1.30 and 1.28 in current assets available to cover every one birr in current liability respectively. Since the banks current ratio are moderate the current asset of the bank are sufficient to cover its current liability.

\section{Asset Management Ratio}

This ratio is employed to evaluate the efficiency with which the firm managed and utilizes its asset. The efficiency of the bank to generate adequate amount of income from its asset can be evaluated using fixed asset turnover ratio and total asset turnover ratio.

\section{Fixed Asset Turnover Ratio}

Fixed Asset Turnover Ratio shows bank's ability in using its existing property, plant asset and equipment to generate income. In 2015 the bank uses its fixed asset of 0.982 times its total revenue and $0.485,0.467$ and 0.510 times of total revenue of 2016, 2017 and 2018 respectively. The trend efficiency of the bank for the last four years can show in the following graph.

Fig 4.2 Fixed Asset Turnover Ratios

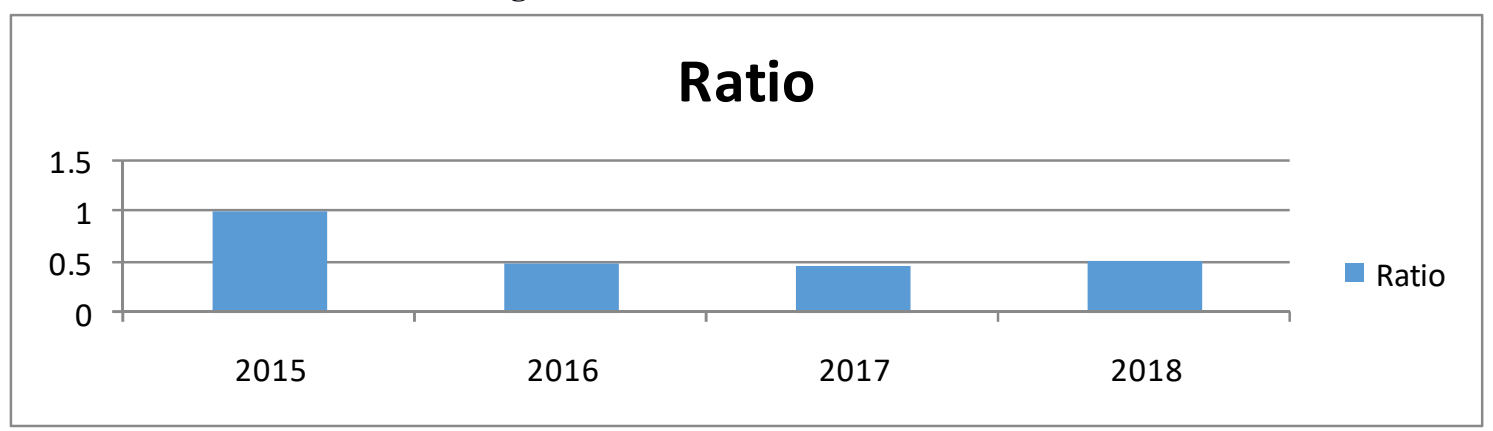

As shown in the graph the fixed asset turns over ratio were fluctuated in the past four years, this implies that the bank's performance in using its fixed asset intensively was decreases from 2015 to2017 and increase in 2018. Total Asset Turnover Ratio

Total asset turnover ratio: indicates how effectively the bank uses its total asset to generate revenue.

Fig 4.3 Total Asset Turnover Ratio

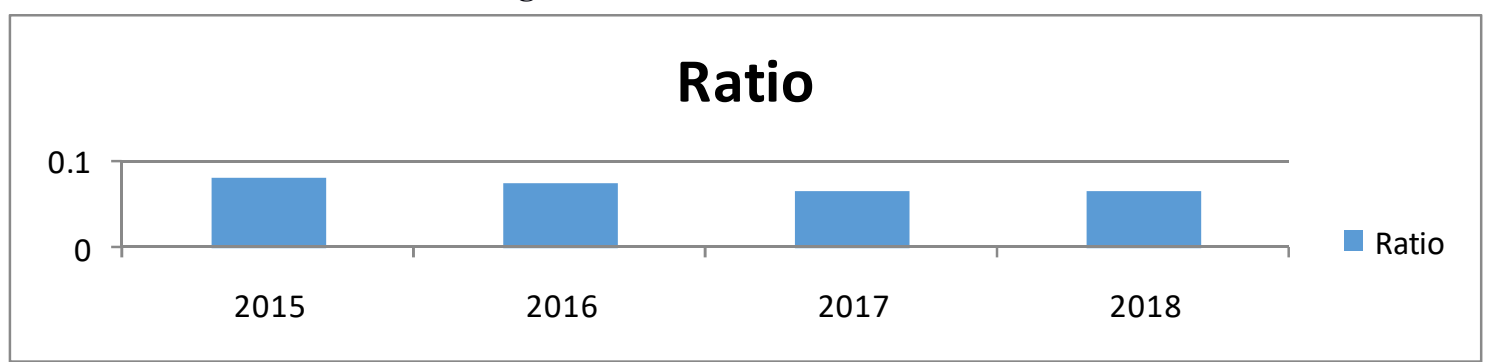

As indicate in the above graph the total asset turnover ratio of the bank has been decreased from 2015 to 2017and increase in 2018. This is clear indication of the banks efficiency in using its total asset in relative to generate revenue and profitability.

\section{Leverage (Debt Management) Ratio}

The purpose of leverage ratio is to indicate the firm's ability to meet both principal and interest payment on the long term obligation. For this analysis purpose debt ratio and time interest earned ratio were used. 
Fig 4.4 Leverage Ratio

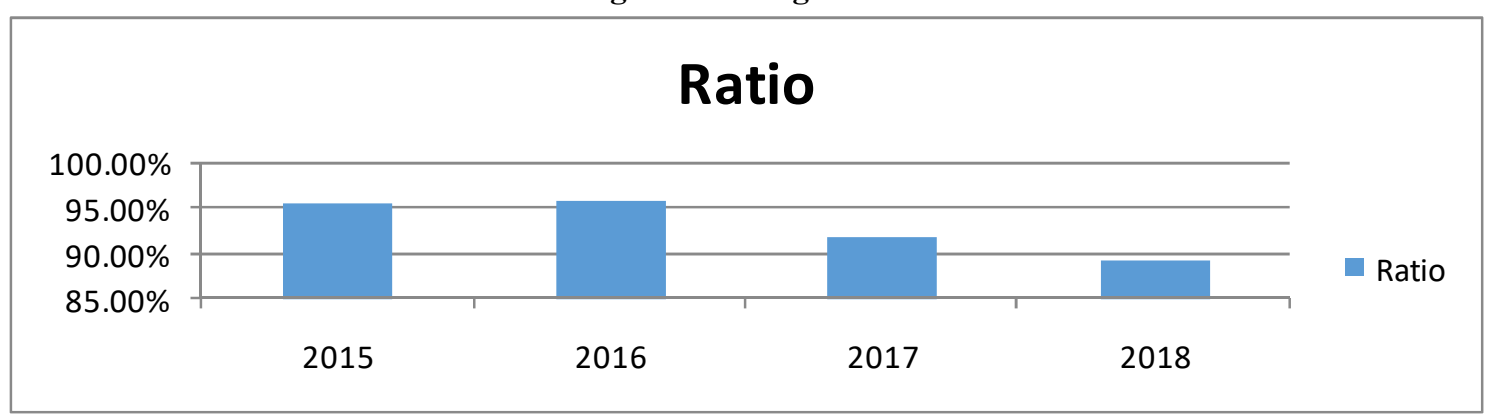

As indicated in the above graph the debt ratio for 2015 to 2016 is relatively increasing and decreasing in 2017 to 2018. It implies that the bank has good capital structure and the firm assets are provided by owner than creditor. As a result creditors may require decreasing the rate of return (interest rate) for taking lower risk in the last two years. In general the lower debt equity ratio is needed meant the higher the degree of protection enjoyed by creditors.

Time Interest Earned Ratio

In the years 2017 to 2018 the bank has an ability to meet its annual interest charge by increasing high margin of safety, but from 2015 to 2016 the bank was in decreasing margin of safety.

Fig 4.5 Time Interest Earned Ratio

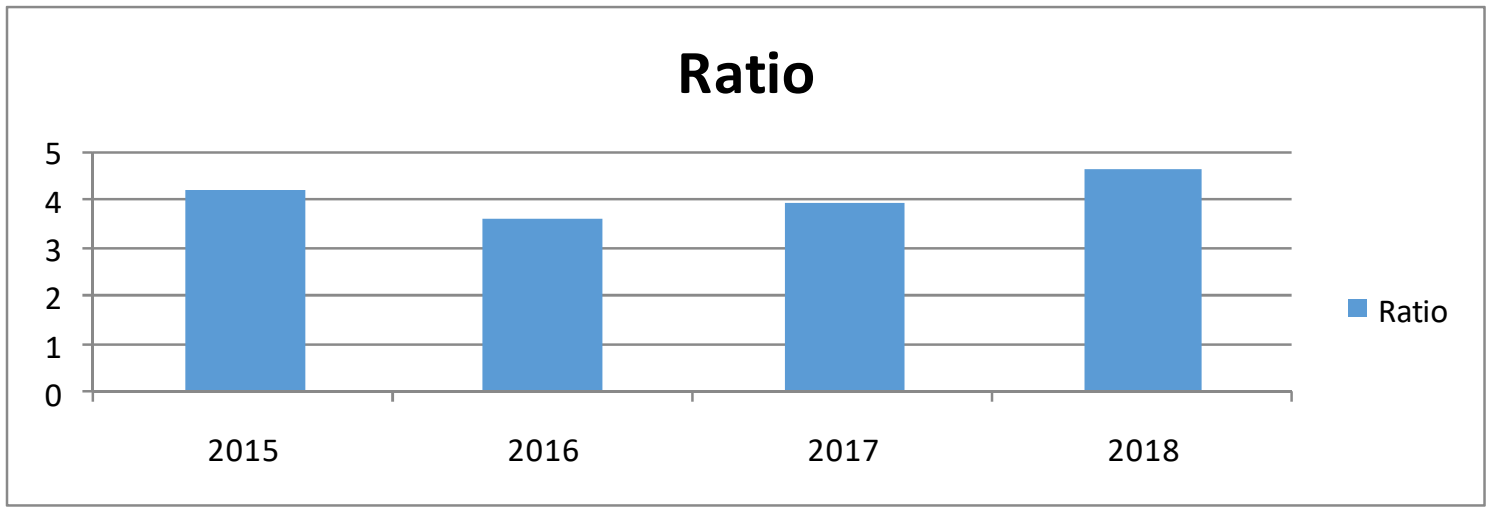

Generally in 2017 and 2018 of margin of safety is good relative to the 2015 and 2016 margin of safety. In the last two years the bank was able to generate operating income to meet its obligation, but in 2015 and 2016 the bank can face some difficulty in rising additional borrowing in the future.

\subsubsection{Profitability Ratio}

These ratios are used to measure the management effectiveness to generate adequate amount of income from operations. For this analysis purpose the basic earning power ratio and return on asset were used. Basic earning power ratio: this ratio indicates the ability of the bank asset to generate income before tax and leverage.

\section{Return on asset}

As shown in the following table Return on asset ratio (ROA): measures the return on total asset after interest and tax.

Table 4.1 Return on asset

\begin{tabular}{|l|l|l|l|l|}
\hline Items & 2015 & 2016 & 2017 & 2018 \\
\hline Net income & 9286.8 & 9986.4 & 11622 & 14812.2 \\
\hline Total asset & 305,075 & 384,693 & 485,700 & 565,500 \\
\hline Ratio & 0.030 & 0.026 & 0.024 & 0.026 \\
\hline
\end{tabular}

Source: Annual report

The bank's return on asset is slightly decrease for the first three consecutive (2015-2017) years and slightly increase for the last (2018) year. This implies that the bank should find out strategies to increase its asset utilization.

\section{Return on Equity}

Return on equity (ROE) ratio: this ratio is the most important accounting ratio which measures the return on common equity. 
Table 4.2 Return on equity

\begin{tabular}{|l|l|l|l|l|}
\hline Items(in million birr) & 2015 & 2016 & 2017 & 2018 \\
\hline Net income & 9286.8 & 9986.4 & 11622 & 14812.2 \\
\hline Total equity & 13,321 & 16,105 & 40,000 & 60,809 \\
\hline Ratio & 0.697 & 0.620 & 0.291 & 0.244 \\
\hline
\end{tabular}

Source: Annual Report

The bank's return on equity was decrease from 2015-2018 and the ratio was $0.697,0.620,0.291$, and 0.244 respectively. It indicates the bank has inefficiency in using its total equity in relative to generate net income.

\section{Conclusion}

The bank's ability to meet current liability by using current asset was fluctuated in the past four years but current asset is cover current liability. The ratios were slightly moderate and enable the bank paying its short term obligation. The fixed asset turnover ratio of Commercial bank of Ethiopia throughout 2015- 2017 slightly decrease but in 2018 was improved. This implies that the bank has good ability in using its property, plant asset and equipment to generate revenue. Also total asset turnover ratio of commercial bank of Ethiopia was decreased from 2015 to 2017 and improved in 2018. This indicates that the bank is effectively using its total resource to generate revenue. Regarding of the ability of bank to meet its annual interest charge Commercial bank of Ethiopia time interest earned ratio show high margin of safety in 2017 and 2018, but in 2016 it was decreased. Commercial bank of Ethiopia basic earning power ratios have been increased from 2006 to 2007 but it shows a slight decrease in 2008. Generally the financial performance of the bank for the last four years was reasonably good when it is evaluated using audited financial statements.

\section{Recommendation}

The findings of this study revealed that the debt management of Commercial bank of Ethiopia signifies a lower ratio for the last two years. A low level of debt introduces inflexibility in the bank's operation due to the increasing interference and pressure by owners. Hence, the bank shall try to increase debt ratio to a reasonable extent and raise additional finance to expand the business as well as increase profitability since debt is known as a cheapest source of fund for business entities than other sources.

\section{REFERENCES}

Abdu's, S. (2004). Bahrain's Commercial Bank Performances during 1994- 2001.

Ahmad, A. U. F., \& Hassan, M. K. (2007). Regulation and Performance of Islamic Banking in Bangladesh, Thunderbird International Business Review, 49(2).

David evince (2003), financial analysis and decision making. Mcgraw hill ; new York

E.F Brigham, collisc. G. (2005). intermediate financial management 5th edition)

Foster G (1978). Financial statement analysis practice; Hall cliff new jerrsy.

Git man, L.J (2004). Principles of Managerial finance 10th editions' Pearson education.

Gokulsinha (2010). Financial statement analysis.

Hassan, Z. (2005a). "Evaluation of Islamic banking performance: On the current use of econometric models", Munich Personal Re PEc Archive Paper No.6461, Posted 27.

Hempel, G. H., \& Simonson, D.G. (1999).’Bank Management: Text and Cases”, Wiley and Sons, 5th edition. Horngren SE.,(2001). introduction to financial accounting,8th edition

Kosmidou, K. (2008). The determinants of banks"e profit in Greece during the Period of EU financial integration", Managerial Finance, 34 (3). Lebanon", International Journal of Business, 9(3), 259-28.

Peters, D., Raad, E. and Sinkey F. Joseph (2004). The performance of banks in postwar Prasonna Chandra,(2001). Investment analysis and portfolio management .

Saleh, A. S. and Z. Ramie (2006). "Islamic Banking Performance in the Middle East: A Case Study of Jordan." Working Paper 06-21, Department of Economics, University of Wollongong.

Www. internet .com /www.cbe.et.annual report .com 


\section{Appendices}

1. The Overall income analysis of commercial bank of Ethiopia annual report of the income analysis are show bellow;

\begin{tabular}{|c|c|c|c|c|c|c|c|c|c|c|}
\hline \multirow[t]{2}{*}{ Items } & \multicolumn{7}{|c|}{ Amount in Million Birr } & \multicolumn{3}{|c|}{ Percentage } \\
\hline & 2015 & 2016 & 2017 & 2018 & $\begin{array}{l}2015 / 1 \\
6\end{array}$ & $\begin{array}{l}2016 / 1 \\
7\end{array}$ & $\begin{array}{l}2017 / 1 \\
8\end{array}$ & $\begin{array}{l}2015 / 1 \\
6\end{array}$ & $\begin{array}{l}2016 / 1 \\
7\end{array}$ & $\begin{array}{l}2017 / 1 \\
8\end{array}$ \\
\hline $\begin{array}{l}\text { Interest } \\
\text { income }\end{array}$ & $\begin{array}{l}16,76 \\
9\end{array}$ & $\begin{array}{l}21,44 \\
4\end{array}$ & $\begin{array}{l}23,46 \\
7\end{array}$ & $\begin{array}{l}27,77 \\
1\end{array}$ & 4,675 & 2,023 & 4,304 & $27.9 \%$ & $9.4 \%$ & $18.3 \%$ \\
\hline $\begin{array}{l}\text { Service } \\
\text { charge }\end{array}$ & 2,759 & 3,033 & 2,085 & 3,389 & 274 & $(948)$ & 1304 & $9.9 \% \%$ & $(31.3 \%)$ & $62.5 \%$ \\
\hline $\begin{array}{l}\text { Gain on } \\
\text { forex } \\
\text { currency } \\
\text { transaction } \\
\text { S }\end{array}$ & 1,962 & 1,360 & 2,303 & 2,089 & $(602)$ & 943 & (214) & $(30.7 \%)$ & $69.3 \%$ & $(9.3 \%)$ \\
\hline $\begin{array}{l}\text { Other } \\
\text { income }\end{array}$ & 2,743 & 2,407 & 2,168 & 3,253 & $(336)$ & (239) & 1085 & $(12.2 \%)$ & $(9.9 \%)$ & $50 \%$ \\
\hline Total & $\begin{array}{l}24,23 \\
3\end{array}$ & $\begin{array}{l}28,24 \\
4\end{array}$ & $\begin{array}{l}30,02 \\
3\end{array}$ & $\begin{array}{l}36,50 \\
2\end{array}$ & 4,011 & 1,779 & 6,479 & $16.6 \%$ & $6.3 \%$ & $21.6 \%$ \\
\hline
\end{tabular}

2. Expense analysis that are interest expense, salary and benefit expense, other expense and doubtful debts are list below;

\begin{tabular}{|c|c|c|c|c|c|c|c|c|c|c|}
\hline \multirow[t]{2}{*}{ Items } & \multicolumn{7}{|c|}{ Amount in Million Birr } & \multicolumn{3}{|c|}{ Percentage (\%) } \\
\hline & 2015 & 2016 & 2017 & 2018 & $2015 / 16$ & $2016 / 17$ & $2017 / 18$ & $2015 / 16$ & $2016 / 17$ & $2017 / 18$ \\
\hline $\begin{array}{l}\text { Interest } \\
\text { expense }\end{array}$ & 4,884 & 6,422 & 6,642 & 6,785 & (1538) & $(220)$ & $(143)$ & $(31.5 \%)$ & $(3.4 \%)$ & $(2.2 \%)$ \\
\hline Salary exp & 3,337 & 4,418 & 3,325 & 4,085 & $(1081)$ & 1093 & $(760)$ & $24.7 \%$ & $(14 \%)$ & $(22.9 \%)$ \\
\hline $\begin{array}{l}\text { Other } \\
\text { expense }\end{array}$ & 534 & 760 & 686 & 945 & $(226)$ & 74 & $(259)$ & $(42.3 \%)$ & $9.7 \%$ & $(37.8 \%)$ \\
\hline Total & 8,755 & 11,600 & 10,653 & 11,815 & $(2845)$ & 947 & $(1,162)$ & $(32.5 \%)$ & $8.16 \%$ & $(10.91 \%)$ \\
\hline
\end{tabular}

3. Deposit analysis of Commercial bank of Ethiopia such as demand deposit, saving deposit and fixed deposit are collected from of annual report of bank are;

\begin{tabular}{|c|c|c|c|c|c|c|c|c|c|c|}
\hline \multirow[t]{2}{*}{ Items } & \multicolumn{7}{|c|}{ Amount in Million Birr } & \multicolumn{3}{|c|}{ Percentage } \\
\hline & 2015 & 2016 & 2017 & 2018 & $\begin{array}{l}2015 / 1 \\
6 \\
\end{array}$ & $\begin{array}{l}2016 / 1 \\
7\end{array}$ & $\begin{array}{l}2017 / 1 \\
8 \\
\end{array}$ & $\begin{array}{l}2015 / 1 \\
6\end{array}$ & $\begin{array}{l}2016 / 1 \\
7\end{array}$ & \begin{tabular}{|l}
$2017 / 1$ \\
8 \\
\end{tabular} \\
\hline $\begin{array}{l}\text { Deman } \\
\text { d } \\
\text { deposit }\end{array}$ & $\begin{array}{l}120,18 \\
3\end{array}$ & $\begin{array}{l}133,82 \\
0\end{array}$ & $\begin{array}{l}135,20 \\
7\end{array}$ & $\begin{array}{l}148,25 \\
2\end{array}$ & 13,637 & 1,387 & 13,045 & $11.3 \%$ & $1.04 \%$ & $9.6 \%$ \\
\hline $\begin{array}{l}\text { Saving } \\
\text { deposit }\end{array}$ & $\begin{array}{l}108,78 \\
8\end{array}$ & $\begin{array}{l}142,62 \\
6\end{array}$ & $\begin{array}{l}177,61 \\
5\end{array}$ & $\begin{array}{l}198,28 \\
9\end{array}$ & 33,838 & 34,989 & 20,674 & $31.1 \%$ & $24.5 \%$ & $11.6 \%$ \\
\hline $\begin{array}{l}\text { Fixed } \\
\text { time } \\
\text { deposit }\end{array}$ & 13,527 & 12,160 & 10,246 & 9,912 & $(1,367)$ & $(1,914)$ & (334) & $\begin{array}{l}(10.1 \% \\
)\end{array}$ & $\begin{array}{l}(15.7 \% \\
)\end{array}$ & $(3.3 \%)$ \\
\hline $\begin{array}{l}\text { Total } \\
\text { deposit }\end{array}$ & $\begin{array}{l}242,49 \\
8\end{array}$ & $\begin{array}{l}288,60 \\
6\end{array}$ & \begin{tabular}{|l|}
323,06 \\
8
\end{tabular} & \begin{tabular}{|l|}
356,45 \\
3
\end{tabular} & 46,108 & 34,462 & 33,385 & $19 \%$ & $11.9 \%$ & $10.3 \%$ \\
\hline
\end{tabular}


4. Current asset, current liability, total equity, revenue, fixed asset and total asset of Annual report of Commercial bank of Ethiopia are show bellow;

( in million birr)

\begin{tabular}{|l|l|l|l|l|}
\hline Items & 2015 & 2016 & 2017 & 2018 \\
\hline Current asset & 280,387 & 326,442 & 417,375 & 492,537 \\
\hline Current liability & 261,434 & 308,837 & 319,837 & 385,872 \\
\hline Total equity & 13,321 & 16,105 & 40,000 & 60,809 \\
\hline Revenue & 24,233 & 28,244 & 31,900 & 37,240 \\
\hline Fixed asset & 24,688 & 58,251 & 68,323 & 72,963 \\
\hline Total asset & 305,075 & 384,693 & 485,700 & 565,500 \\
\hline
\end{tabular}

5. The annual report of Commercial bank of Ethiopia EBIT, Net income and total debts are show below; ( in million birr)

\begin{tabular}{|l|l|l|l|l|}
\hline Items & 2015 & 2016 & 2017 & 2018 \\
\hline EBIT & 20,362 & 23,066 & 26,012 & 31,472 \\
\hline Net income/loss & 9286.8 & 9986.4 & 11622 & 14812.2 \\
\hline Total debt & 291,754 & 368,588 & 445,700 & 504,691 \\
\hline
\end{tabular}

Source: Annual Report of the Bank (2015-2018) 